\title{
Molecular Analysis of Patients With Type III Bartter Syndrome: Picking Up Large Heterozygous Deletions With Semiquantitative PCR
}

\author{
KANDAI NOZU, XUE JUN FU, KOICHI NAKANISHI, NORISHIGE YOSHIKAWA, HIROSHI KAITO, KYOKO KANDA, \\ RAFAL PRZYBYSLAW KROL, RITSUKO MIYASHITA, HIDEKAZU KAMITSUJI, SHOICHIRO KANDA, YOSHIKI HAYASHI, \\ KENICHI SATOMURA, NOBUHIKO SHIMIZU, KAZUMOTO IIJIMA, AND MASAFUMI MATSUO
}

Department of Pediatrics [K.N., X.J.F., H.K, K.K., R.P.K., M.M.], Kobe University Graduate School of Medicine, Kobe, Hyogo, 6500017, Japan; Department of Pediatrics [K.N., N.Y.], Wakayama Medical University, Wakayama, 6418509, Japan; Department of Pediatrics [R.M.], Izumiotsu Municipal Hospital, Izumiotsu, Osaka, 5950027, Japan; Kamitsuji Children's Clinic [H.K.], Nara, 6310011, Japan; Department of Pediatrics [S.K., Y.H.], Ome Municipal General Hospital, Tokyo, 1980042, Japan; Division of Pediatric Nephrology and Metabolism [K.S., N.S], Osaka Medical Center and Research Institute for Maternal and Child Health, Izumi, Osaka, 5941101, Japan; Department of Nephrology [K.I.], National Center for Child Health and Development, Tokyo, 1578535, Japan

\begin{abstract}
Type III Bartter syndrome (BS) (OMIM607364) is caused by mutations in the basolateral chloride channel $\mathrm{ClC}-\mathrm{Kb}$ gene $(C L C N K B)$. The $C L C N K B$ gene is sometimes reported as having a large deletion mutation, but all cases reported previously were large homozygous deletions and a large heterozygous deletion is impossible to detect by direct sequencing. This report concerns a genetic analysis of five Japanese patients with type III BS. To identify the mutations, we used polymerase chain reaction (PCR) and direct sequencing. To detect large heterozygous deletion mutations of the CLCNKB gene, we conducted semiquantitative PCR amplification using capillary electrophoresis. The result was that four mutations were identified, comprising one novel 2-bp deletion mutation, an entire heterozygous deletion, and a heterozygous deletion mutation of exons 1 and 2. The nonsense mutation W610X was detected in all patients, and this mutation is likely to constitute a founder effect in Japan. Capillary electrophoresis is a new method and extremely useful for detecting large heterozygous deletions, and should be used to examine type III BS cases in whom only a heterozygous mutation has been detected by direct sequencing. This is the first report to identify large heterozygous deletion mutations in the CLCNKB gene in patients with type III BS. (Pediatr Res 62: 364-369, 2007)
\end{abstract}

$\mathrm{B}$ artter Syndrome (BS) is an autosomal recessive inherited disorder characterized by hypokalemic metabolic alkalosis with normal or low blood pressure despite hyperreninemia and hyperaldosteronemia. Recent genetic studies have found that this disease is caused by mutations, which lead to transporter or channel loss-of-function directly or secondary in several genes. The first gene is the SLC12Al gene, which encodes the apical $\mathrm{Na}-\mathrm{K}-2 \mathrm{Cl}$ cotransporter (NKCC2), the second is the KCNJ1 gene, which encodes the apical renal outer medullary $\mathrm{K}$ channel (ROMK), and the third is the $C L C N K B$ gene, which encodes the basolateral $\mathrm{Cl}$ channel $\mathrm{Kb}$ $(\mathrm{ClC}-\mathrm{Kb})$ expressed in the thick ascending limb of Henle's

Received February 21, 2007; accepted April 22, 2007.

Correspondence: Kandai Nozu, M.D., Ph.D., Department of Pediatrics, Kobe University Graduate School of Medicine, Kobe 650-0017, Kusunokicho 7-5-1, Chuo, Kobe, Hyogo, Japan; e-mail: nozu@med.kobe-u.ac.jp

This work was supported by grants from the Ministry of Education, Culture, Sports, Science and Technology of Japan Running. loop. The mutations of these genes lead to type I-III BS (1-4). In recent years, a combination of antenatal BS and sensorineural deafness has been recognized, whose responsible gene has been identified as $B S N D$ coding barttin, a subunit for $\mathrm{ClC}-\mathrm{Ka}$ and $\mathrm{ClC}-\mathrm{Kb}$, and this phenotype is now known as type IV BS (5). Moreover, the discovery of type V BS, associated with hypoparathyroidism, has been reported, and this type was found to be due to a gain of function mutations in the calcium sensing receptor, and the responsible coding gene is known as CASR $(6,7)$.

It has previously been reported that some of the type III BS patients carry gross deletions $(4,8-10)$, but all reported cases possess homozygous deletions, whereas heterozygous deletion mutations have not been reported because this kind of mutation is undetectable with standard PCR and sequencing. Moreover, some previously reported cases possess only heterozygous mutations and another mutations were missing $(8,10)$. Some of these cases may attributable to the methodological problem of direct sequencing.

This report describes the results of genetic analysis of five patients with type III BS, including the detection of large heterozygous deletions in $C L C N K B$.

\section{METHODS}

Patients. All procedures were reviewed and approved by the ethics committees of Kobe University.

The study was initiated after written informed consent had been obtained from all five type III BS patients and their family members. The patients were followed up at four regional hospitals in Japan: Izumiotsu Municipal Hospital, Izumiotsu; Kamitsuji Children's Clinic, Nara; Ome Municipal General Hospital, Tokyo; and Osaka Medical Center and Research Institute for Maternal and Child Health, Osaka. BS was diagnosed based on the following four criteria: (1) severe hypokalemia ( $<3 \mathrm{mEq} / \mathrm{L})$, (2) metabolic alkalosis, (3) normotensive or hypotension hyperreninemic hyperaldosteronism, (4) no drug abuse (diuretics or cathartics), anorexia nervosa, or chronic diarrhea. We could not get the consent for genetic analysis from the father of patient B.

Abbreviations: BS, Bartter syndrome; ClC-Kb, $\mathrm{Cl}$ channel KbNKCC2 NaK-2Cl cotransporter; ROMK, renal outer medullary K channel; SNPs, single nucleotide polymorphisms 
Data collection. Conditions of the patients' perinatal and infantile period were recorded. The lowest serum concentrations of potassium and magnesium were used for analysis.

Mutation analysis. Total DNA was extracted and purified from peripheral leukocytes in whole-blood samples with the standard phenol-achloroform extraction method. Specific exons of $C L C N K B$ were amplified by PCR. PCR-amplified products were purified and directly subjected to sequencing. For the sequence analysis, a Dye terminator cycle sequencing kit (Amersham Bioscience, Piscataway, NJ) was used with an automatic DNA sequencer (model ABI Prism 310; Perkin Elmer Applied Biosystems, Foster City, CA). Some of the primers for the genomic gene of $C L C N K B$ were newly designed, as shown in Table 1, specifically to amplify the $C L C N K B$ gene because of its $>90 \%$ sequence identity with the CLCNKA gene and because primers used in previously reported studies amplified both CLCNKA and CLCNKB in some of the exons (11). To detect a large heterozygous deletion mutation in patient $D$ and his father, we used a forward primer within the CLCNKA intron 15 whose design is as follows: CCAAGGTCTTCCGGAAGCTTG.

Semiquantitative PCR amplification. Heterozygous gross CLCNKB gene deletion in patients $\mathrm{C}$ and $\mathrm{D}$ was detected with semiquantitative PCR amplification using capillary electrophoresis. PCR cycling conditions were as follows: initial denaturation at $94^{\circ} \mathrm{C}$ for $5 \mathrm{~min}$ followed by 20 cycles of denaturation at $94^{\circ} \mathrm{C}$ for $45 \mathrm{~s}$, annealing at $55^{\circ}-60^{\circ} \mathrm{C}$ for $45 \mathrm{~s}$, extension at $72^{\circ} \mathrm{C}$ for $2 \mathrm{~min}$, and a final extension at $72^{\circ} \mathrm{C}$ for $5 \mathrm{~min}$. To quantify the amplified products, $1 \mu \mathrm{L}$ of each reaction mixture mixed with $5 \mu \mathrm{L}$ of the loading buffer solution containing size markers (15 and $1500 \mathrm{bp}$ ) was analyzed by capillary electrophoresis (Agilent 2001 Bioanalyzer with DNA 1000 Lab Chips; Agilent Technologies, Palo Alto, CA). Each of the PCR products was quantified by measuring the peak area and calculating the ratio of the key exons of the $C L C N K B$ to exons of completely different genes for internal control. Two exon fragments, including the one corresponding to CLCNKB exons and an internal control fragment (primer pairs for $S L C 12 A 1$ exon 1, 22, or $S L C 12 A 3$ exon 19) were coamplified in one PCR reaction. The internal control primers were selected according to the condition of PCR amplification and PCR product size, because, to coamplify primers with CLCNKB exons in the same tube, it is necessary to have exactly the same PCR conditions to get equally amplified PCR products and the product must have a different size for electrophoresis. All family members of patients C and D and normal control subjects were analyzed at the same time with this method.

\section{RESULTS}

Patient characteristics. Table 2 shows the patients' clinical features. Patients A-1, A-2, and C showed antenatal clinical symptoms, but none of the five patients had nephrocalcinosis. From the laboratory data, renal function was within normal range at this time.

Table 3 shows the patients' laboratory data. All of them had low serum potassium and high plasma renin activity and, except for patient $\mathrm{C}$, a relatively low serum magnesium level.

Mutational analysis and semiquantitative PCR amplification. Table 4 shows the mutations in the CLCNKB gene of all patients.

Patients $\boldsymbol{A}-1$ and $\boldsymbol{B}-2$. A homozygous mutation of $C L C N K B$, W610 $\times($ c.1830G $>$ A in exon 16), was detected. Both of their parents were found to carry the heterozygous W610X mutation, but their older brother was not. There were no apparent clinical symptoms or laboratory data abnormalities (Fig. 1A).

Patient B. A compound heterozygous mutation of CLC$N K B$, W610X (c.1830G $>\mathrm{A}$ in exon 16) and a frame shift at codon 445 (c.1334_1335delCT in exon 13) were detected. The small deletion mutation of c.1334_1335delCT constitutes a novel mutation. The patient's mother was found to carry the heterozygous W610X mutation, whereas neither of his parents showed any apparent clinical symptoms or laboratory data abnormalities (Fig. 1B).

Patient $C$. The results of direct sequencing suggested a homozygous mutation of $C L C N K B$, W610X (c.1830G $>\mathrm{A}$ in exon16), and the patient's mother carried the heterozygous

Table 1. Primers for the CLCNKB gene analysis

\begin{tabular}{|c|c|c|}
\hline Exon & Sense $\left(5^{\prime}-3^{\prime}\right)$ & Antisense $\left(5^{\prime}-3^{\prime}\right)$ \\
\hline 1 & ACTGGAAGGGCCTAGAGGCAGT & GATGTCCTGAGTGGTCCTCCAG \\
\hline 2 & TGCCCCACCCTGTGCCGTGAC & CTTGGCCCAGAGCAGCACCTG \\
\hline 3 & GAGGCTGTGGGTGCCTCCCTG & ATGAGGCTGCCCCTTCCCGAC* \\
\hline 5,6 & CAGAGGGGACTTGGGCTGGTC* & GGAGGAGCTTGAGGGACCCAG \\
\hline 7 & GTTTGAAATCCACGTATGACC* & GCAGGGCCAGGGTCAGGCAG \\
\hline 8 & CGCCATCTTGGCTCCCCACTG & GGGAGCATGGAGACATGAGC* \\
\hline 11 & CTCAGCATTATTTTATAGATG* & GTCCCAGCTCTGTGCACACCTG \\
\hline 12,13 & GTTTACTGGGAAGGCTAAGG** & CACGACATTGCCCACGCAGCAG \\
\hline 14 & GTCGCAGCCGTGCCAGCCTTG* & GACTCAGCCTGAGGTGGGCAC \\
\hline 15 & CACATCCCTGACTGTGGGGC* & СCTACCCCCGACTTCCTCCTC \\
\hline 16,17 & GAACAGTTCTTGGCTAAGTAGGTG & CCAGAGGCCTCATGTGTCACAC \\
\hline 18 & GGGCACCTTCTACCCTCCAGTG & GTCTTCTCAGGCATAGGTTCCCTG \\
\hline
\end{tabular}

*Newly designed.

Table 2. Clinical characteristics of the five patients

\begin{tabular}{cclccccc}
\hline Patient & Age, y & Sex & Polyhydramnios & $\begin{array}{c}\text { Gestational age } \\
\text { and weight }\end{array}$ & $\begin{array}{c}\text { Onset age } \\
\text { and symptoms }\end{array}$ & $\begin{array}{c}\text { Short } \\
\text { stature }\end{array}$ & Nephrocalcinosis \\
\hline A-1 & 13 & Female & + & $40 \mathrm{wk}, 3250 \mathrm{~g}$ & 1 mo, failure to thrive & + & - \\
A-2 & 12 & Female & + & $40 \mathrm{wk}, 3840 \mathrm{~g}$ & Antenatal & + & - \\
B & 20 & Male & - & $39 \mathrm{wk}, 3500 \mathrm{~g}$ & 6 mo, failure to thrive & - & - \\
C & 14 & Female & + & $36 \mathrm{wk}, 2723 \mathrm{~g}$ & 2 mo, failure to thrive & + & - \\
D & 5 & Male & - & $37 \mathrm{wk}, 2922 \mathrm{~g}$ & 12 d, failure to thrive & - & - \\
\hline
\end{tabular}


Table 3. Laboratory findings of the five patients

\begin{tabular}{|c|c|c|c|c|c|c|c|c|}
\hline Patient & $\begin{array}{c}\text { Serum K } \\
(\mathrm{mEq} / \mathrm{L})\end{array}$ & $\begin{array}{c}\text { Serum Mg } \\
(\mathrm{mg} / \mathrm{dL})\end{array}$ & $\begin{array}{c}\text { PRA } \\
(\mathrm{ng} / \mathrm{mL} / \mathrm{h})\end{array}$ & $\begin{array}{l}\text { Aldosterone } \\
(\mathrm{pg} / \mathrm{mL})\end{array}$ & $\begin{array}{c}\mathrm{BE} \\
(\mathrm{mmol} / \mathrm{L})\end{array}$ & $\begin{array}{c}\text { BUN } \\
(\mathrm{mg} / \mathrm{dL})\end{array}$ & $\begin{array}{c}\mathrm{Cr} \\
(\mathrm{mg} / \mathrm{dL})\end{array}$ & $\begin{array}{l}\text { Urine } \mathrm{Ca} / \mathrm{Cr} \\
(\mathrm{mg} / \mathrm{mg})\end{array}$ \\
\hline A-1 & 2.4 & 1.8 & 20 & $>2500$ & 14.7 & 7.7 & 0.2 & $0.02-0.2$ \\
\hline A-2 & 2.7 & 1.9 & 20 & 450 & 11.9 & 16.1 & 0.3 & $0.08-0.14$ \\
\hline $\mathrm{C}$ & 1.6 & 2.3 & 80 & - & 29.4 & 13.4 & 0.29 & 0.81 \\
\hline $\mathrm{D}$ & 2.6 & 1.7 & $>20$ & 391 & 11.3 & 17.1 & 0.27 & 0.42 \\
\hline Normal range & $3.6-5.0$ & $1.8-2.6$ & $*$ & $\dagger$ & 0 & $6-20$ & $0.6-1.0$ & $0.1-0.3$ \\
\hline
\end{tabular}

PRA, plasma renin activity; BE, base excess; BUN, blood urea nitrogen.

*Normal values for PRA in Japanese children are as follows: for the age $5 \mathrm{y}, 1.76 \pm 0.99$; for the age range $12-15 \mathrm{y}, 0.91 \pm 0.42$; and for the adult, $1.01 \pm 0.14$ (personal communication from Japanese Public Health Association).

$\dagger$ Normal values for aldosterone in Japanese children are as follows: for males age $5 \mathrm{y},<280$; for females age $12 \mathrm{y},<415$; for females age $13 \mathrm{y},<435$; for females age 14 y, <462; and for adults (personal communication from Japanese Public Health Association).

Table 4. Mutations in CLCNKB in the five patients

\begin{tabular}{cllll}
\hline Patient & \multicolumn{1}{c}{ Mutation 1 } & \multicolumn{1}{c}{ Mutation 2 } & \multicolumn{1}{c}{ Father } & Mother \\
\hline A-1 & W610X (homozygous) & & W610X (heterozygous) & W610X (heterozygous) \\
A-2 & W610X (homozygous) & & & \\
B & W610X (heterozygous) & Frameshift 4451 (heterozygous) & Not done & W610X (heterozygous) \\
C & W610X (heterozygous) & Entire deletion (heterozygous) & Entire deletion (heterozygous) & W610X (heterozygous) \\
D & W610X (heterozygous) & Exon 1-2 deletion (heterozygous) & Exon 1-2 deletion (heterozygous) & W610X (heterozygous) \\
\hline
\end{tabular}
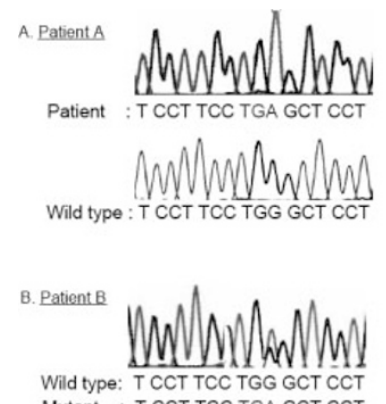

Mutant : T CCT TCC TGA GCT CCT

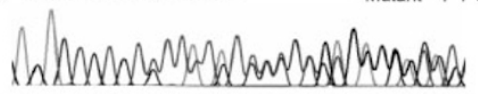

C. Patient C

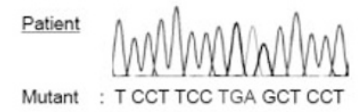

Father
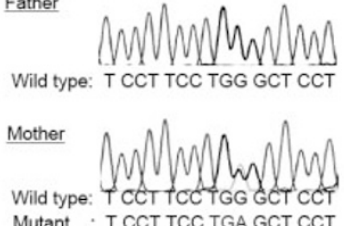

Mutant : T CCT TCC TGA GCT CCT

Wild type: AG ACT CTC TCT TTT ATC TTC CCT GAG GGC AT Mutant : AG ACT CTC TTT TAT CTT CCC TGA GGG CAT CG

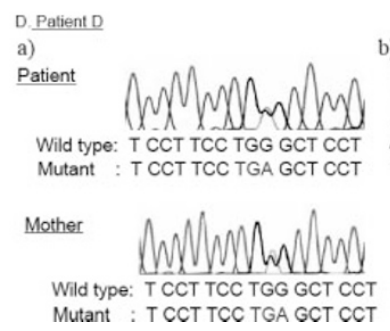

Figure 1. Detection of $C L C N K B$ mutations by direct sequencing. (A) Homozygous nonsense mutation of $C L C N K B$, W610X (c.1830G $>\mathrm{A}$ in exon 16) in patients A-1 and A-2. (B) Heterozygous nonsense mutation of $C L C N K B$, W610X (c.1830G $>$ A in exon 16: top) and novel heterozygous deletion mutation of $C L C N K B$, c.1334_1335delCT, in exon 13 (bottom) in patient B. (C) Homozygous nonsense mutation of $C L C N K B$, W610X (c.1830G $>\mathrm{A}$ in exon 16) in patient $C$. Although the patient's mother showed heterozygous nonsense mutation of W610X, her father did not. (D) a) Heterozygous nonsense mutation of $C L C N K B$, W610X (c.1830G $>\mathrm{A}$ in exon 16) in patient D. The patient's mother showed heterozygous nonsense mutation of W610X. b) Heterozygous large deletion mutation from $C L C N K A$ exon 16 to $C L C N K B$ intron 2 was detected in patient $\mathrm{D}$ using primer pairs whose position is shown in Figure 4. The $5^{\prime}$ breakpoint was the 46 base pair of the CLCNKA exon 16 and the $3^{\prime}$ was within the intron 2 (exon 3-185 base pair) of the CLCNKB.
W610X mutation, but the patient's father did not (Fig. 1C). Moreover, the single nucleotide polymorphisms (SNPs) analysis of c.1971T $>C$ (in exon 18) showed that the father carried the homozygote of $\mathrm{T}$ but the patient the homozygote of $\mathrm{C}$ (Fig. $2 C$ ). The father and the patient were therefore expected to possess a large heterozygous deletion of the $C L C N K B$ gene and the result of the direct sequencing appears to indicate that the patient carried a homozygous W610 mutation. That is to say, the patient was believed to possess a compound heterozygous mutation of the nonsense mutation and a large deletion of $C L C N K B$ including exons 16 and 18 . Following these findings, we conducted semiquantitative PCR amplification using capillary electrophoresis. The results disclosed that the patient and her father had half the quantity of PCR products of all $C L C N K B$ exons as did her mother and the normal control (only the results of exons 1 and 19 are shown in Fig. 3A, B), indicating a reduction in the copy numbers in the entire $C L C N K B$ gene of the patient and her father. This means that the patient had a compound heterozygous mutation of W610X and deletion of the entire CLCNKB. Her parents had no apparent clinical symptoms or laboratory data abnormalities.

Patient D. Only a heterozygous mutation of CLCNKB, W610X (c.1830G $>A$ in exon 16), was detected and the patient's mother was found to carry the heterozygous W610X mutation (Fig. 1D-a). However, the SNPs analysis of c. $80 \mathrm{G}>\mathrm{T}$ (in exon 1) showed that the father carried the homozygote of $\mathrm{T}$ and the patient the homozygote of $\mathrm{G}$ (Fig. $2 D$ ). These results suggested that the patient and her father might have a large deletion around exon1. We conducted semiquantitative PCR amplification using capillary electrophoresis. The results showed that the patient and her father had half the quantity of PCR products of $C L C N K B$ exons 1 and 2 than her mother and the normal control and the same quantity of exon 3 to exon 19 (only the results of exons 2 and 3 are shown in Figure $3 C, D$ ). These results indicated a reduction in the copy numbers in exons 1 and 2 of $C L C N K B$ 

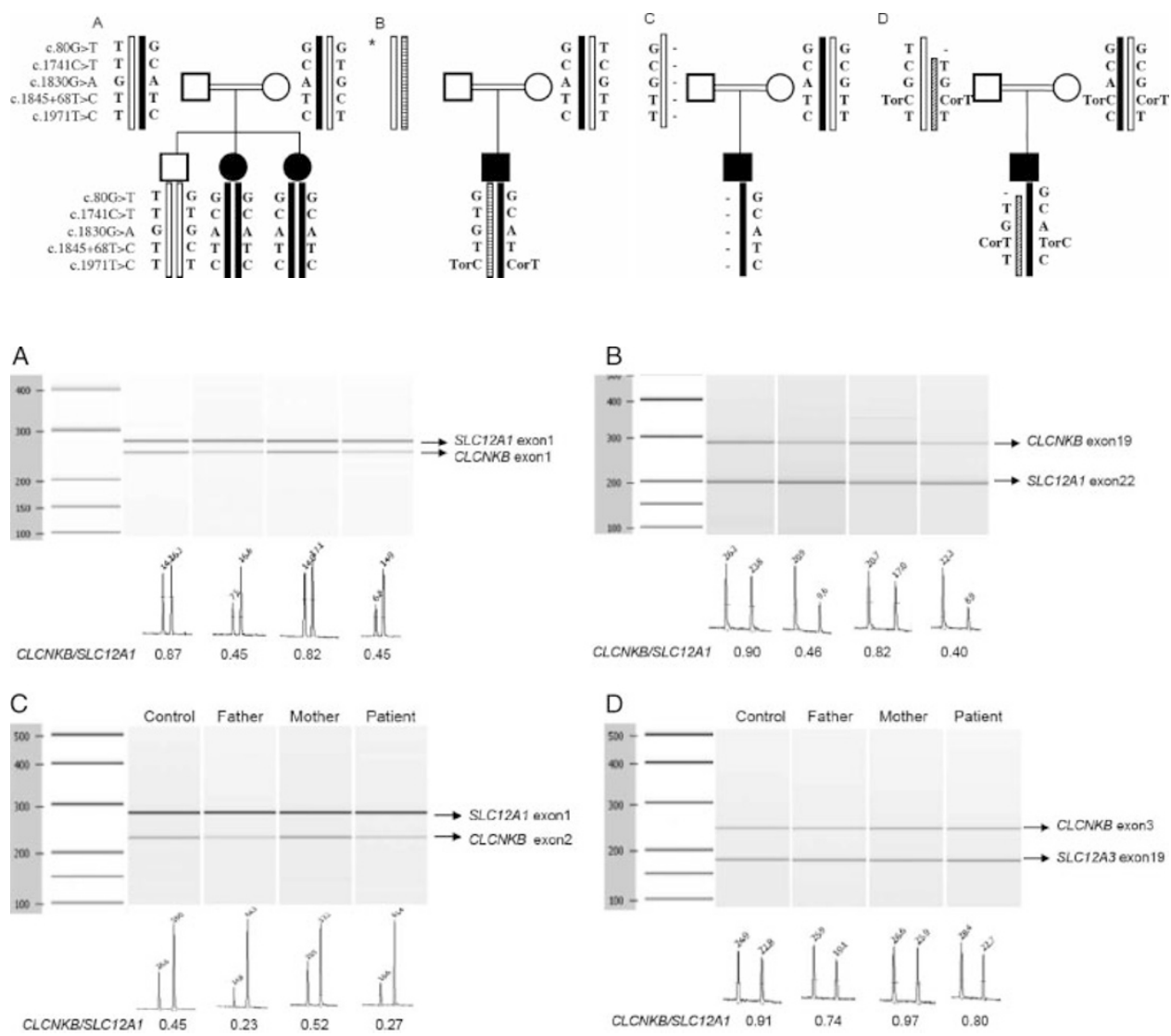

Figure 2. Haplotype reconstruction relative to five markers (four SNPs and one mutation) in the $C L C N K B$ of four families. Markers from the top: c. $80 \mathrm{G}>\mathrm{T}$ (in exon 1), c.1741C $>\mathrm{T}$ (in exon 15), c.1830G $>\mathrm{A}$ (W610X), IVS16 + 68T $>C$ (in intron 16), and c.1971T $>\mathrm{C}$ (in exon 18). *We could not get the consent for genetic analysis from the father of the patient $\mathrm{B}$.

Figure 3. Semiquantitative PCR amplification of the CLCNKB gene. Capillary electrophoretic patterns of PCR products. $(A, B)$ Patient C. (A) $C L C N K B$ exon 1 and SLC12A1 exon 1 (internal control). (B) $C L C N K B$ exon 19 and $S L C 12 A 1$ exon 22 (internal control). The peak areas of $C L C$ $N K B$ exons 1 and 19 in the patient and her father are only about half of those in her mother and the normal control. $(C, D)$ Patient D. (C) CLCNKB exon 2 and $S L C 12 A 1$ exon 1 (internal control). (D) $C L C N K B$ exon 3 and SLC12A3 exon 19 (internal control). In the patient and her father, the peak areas of $C L C N K B$ exon 2 is only about half and those of exon 3 is the same as in her mother and the normal control. gene of the patient and her father. This means that the patient had a compound heterozygous mutation of W610X and CLC$N K B$ exon 1 and 2 deletion. Following these results, we conducted an analysis to detect the breakpoint of the large heterozygous deletion mutation by a genome-walking technique toward the CLCNKA gene and revealed that the 5' deletion breakpoint was located in exon 16 of the CLCNKA gene. The forward primer within intron 15 of the CLCNKA gene and the reverse primer within intron 3 of the $C L C N K B$ gene were used for PCR and generated a 522-bp amplicon in the patient and the father, who was suggested to have a heterozygous large deletion mutation by semiquantitative PCR (Fig. 4). The result of the direct sequencing of this PCR product shows the breakpoint of the large deletion (Fig. 1D-b). Her parents showed no apparent clinical symptoms or laboratory data abnormalities.

Generation of polymorphic markers to the CLCNKB gene. All patients and family members were examined for markers of four SNPs and c.1830G > A (W610X) mutation. The findings for the four SNPs were as follows: c.80G $>\mathrm{T}$ (in exon 1), c. $1741 \mathrm{C}>\mathrm{T}$ (in exon 15), c. $1845+68 \mathrm{~T}>\mathrm{C}(\mathrm{IVS} 16+68)$, and c.1971T $>C$ (in exon 18). The results of haplotype construction for the four family members are shown in Figure 2. The loci with c.1830A (W610X) mutation had exactly the same polymorphic pattern, suggesting that the W610X mutation may constitute a founder effect in the Japanese population.

SNPs in CLCNKB. A number of nucleotide exchanges were detected in this study. Some were silent mutations without an amino acid exchange. Others led to an amino acid exchange, but were detected also in healthy control subjects or reported previously as polymorphisms. Those were implicated the following amino acids: F4L (c.10T $>$ C), R27L (c.80G $>$ T), S108S (c.324A>G), S195I (c.584G>T), Q197 K (c.589C $>$ A), A287V (c.860C $>$ T), Q356Q (c.1068G $>$ A), $\mathrm{S} 195 \mathrm{I} \quad(\mathrm{c} .584 \mathrm{G}>\mathrm{T}), \quad \mathrm{M} 562 \mathrm{~T} \quad(\mathrm{c} .1685 \mathrm{~T}>\mathrm{G}), \quad \mathrm{K} 578 \mathrm{E}$ (c.1732A $>$ G), L581L (c.1741C $>$ T), F657F (c.1971T $>$ C), P683P (c.2049G > T), IVS5-5c >t, IVS10 + 5g >a, IVS16 + $68 \mathrm{~T}>\mathrm{C}$.

\section{DISCUSSION}

In the study presented here, several mutations were identified, including one novel mutation, and heterozygous gross deletion mutations in five Japanese patients with type III BS, all of whom met the clinical criteria for antenatal or classic BS. Genetic diagnosis confirmed that all the patients had type III BS.

Type III BS is generally classified as classic BS because patients are usually diagnosed while they are infants and lack nephrocalcinosis or renal insufficiency; characteristics that differentiate patients with type III BS from type I and II BS $(2,3,8,12,13)$. BS patients show hypercalciuria and normal magnesium levels. Recently, however, some studies have disclosed that the clinical character of type III BS involves a highly variable phenotype ranging from episodes of severe dehydration during the neonatal period to almost asymptomatic patients diagnosed during adolescence. Moreover, some cases feature hypocalciuria and/or hypomagnesemia, which 

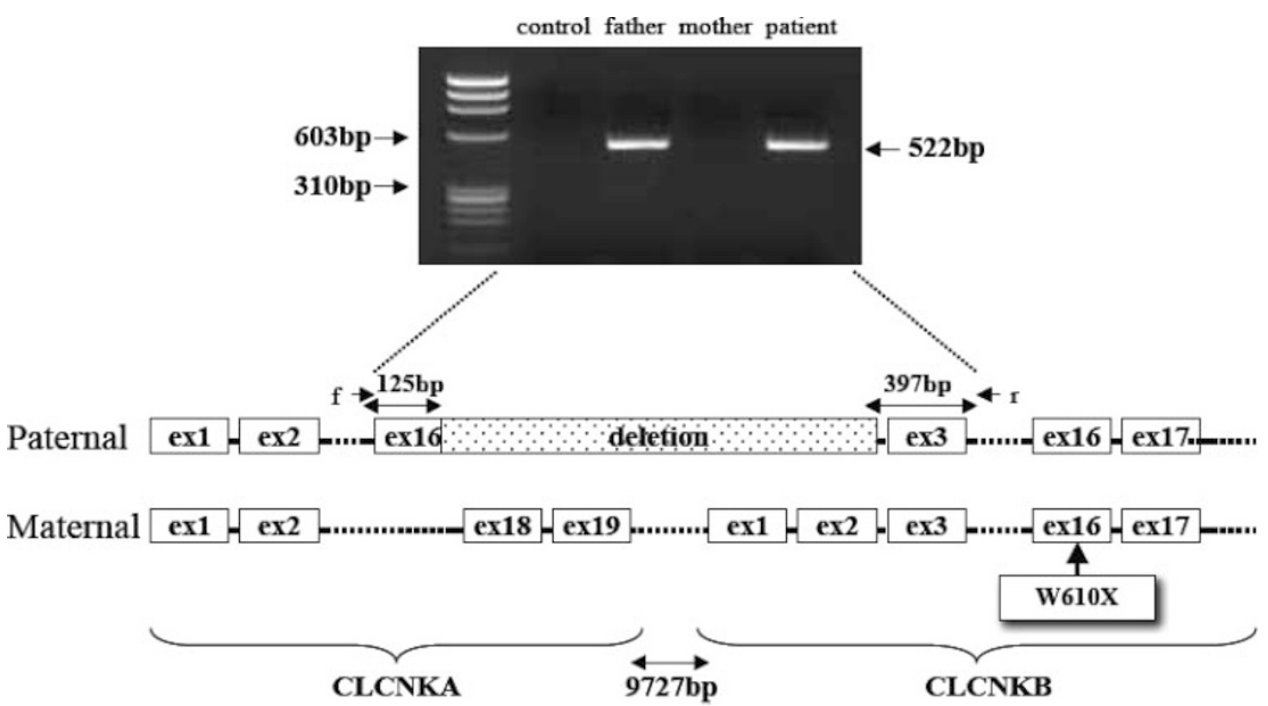

Figure 4. Detection of large heterozygous deletion mutation in patient $\mathrm{D}$. The forward primer within intron 15 of the CLCNKA gene and the reverse primer within intron 3 of the $C L C N K B$ gene are indicated by arrows. Amplification by PCR with this primer pair generated a 522-bp amplicon, which was detected in patient and the father, who was suggested to have a heterozygous large deletion mutation by semiquantitative PCR. The result of the direct sequencing of this PCR product is shown in Figure $1 D-b$ ). sometimes mislead the type III BS to Gitelman syndrome, as reported previously $(8,12,14)$.

The results of our study raise two novel points in genetic analysis of type III BS cases.

The first point concerns the W610X nonsense mutation in $C L C N K B$. This mutation was previously detected in six unrelated Japanese BS patients $(11,14,15)$ and was found in all five patients in our study. Most of these cases are from completely disparate localities in Japan, which leads to the hypothesis that this may be a founder mutation in Japan. In fact, haplotype construction using polymorphic markers localized at the $C L C N K B$ locus for these families suggests a common ancestry.

The second point concerns the detection of large heterozygous deletion mutations. These kinds of mutations are very difficult to detect because they are undetectable with a standard PCR and direct sequencing. The most commonly applied techniques to detect these mutations are fluorescent in situ hybridization (FISH) and Southern blotting. FISH analysis has been preferred because it allows for visual determination of the copy number in the region examined. However, the method is complicated, expensive, and time-consuming. Southern blot is simpler than FISH, but depends greatly on technical skill and is more laborious than semiquantitative PCR. To date, some authors have used capillary electrophoresis to detect heterozygous deletions $(16,17)$, as did we in our study, and clearly detected a large heterozygous deletion. Previously, several authors have reported the presence of gross homozygous deletions in the CLCNKB gene, and it is relatively easy to find a wide range of deletions in this gene $(4,8-10)$. This mechanism has recently been clarified and named the rearrangement theory (18). The clarification was facilitated by the presence of the region specific low-copy repeats $C L C N K A$ and $C L C N K B$, which have more than $90 \%$ sequence identity. Some previous reports have dealt with BS cases with only a heterozygous mutation in CLCNKB $(4,7,8,15)$, but the missing mutations in some of these cases may be attributable to the methodological problem of direct sequencing. Ours is thus the first report to identify large heterozygous deletion mutations in the CLCNKB gene in patients with type III BS. Moreover, we can also say that in cases with one homozygous mutation, there remains the possibility that this homozygosity is due to the complete absence of the second allele, as seen in patient $\mathrm{C}$ in this report. This can only be clarified by family analysis. But in routine genetic testing, it is conducted mainly in single sporadic patients using direct sequencing, and in this situation, large heterozygous deletions may sometimes be missing.

To summarize, we used direct sequencing and semiquantitative PCR amplification to identify one novel mutation and two large heterozygous $C L C N K B$ deletions in five Japanese patients with type III BS, and ours is the first study using this method to detect a large heterozygous deletion in inherited kidney disease. This kind of mutation warrants investigation in patients with type III BS with only a heterozygous mutation. Furthermore, we hypothesize that the nonsense mutation W610X is a founder effect of Japanese population.

In conclusion, type III BS cases with only a heterozygous mutation detected by means of direct sequencing should be further examined for detection of the possible presence of a large heterozygous deletion mutation.

Acknowledgments. The authors thank Yoshimi Nozu for her help in genetic analysis.

\section{REFERENCES}

1. Bartter FC, Pronove P, Gill JR Jr, Maccardle RC 1962 Hyperplasia of the juxtaglomerular complex with hyperaldosteronism and hypokalemic alkalosis. A new syndrome. Am J Med 33:811-828

2. Simon DB, Karet FE, Hamdan JM, DiPietro A, Sanjad SA, Lifton RP 1996 Bartter's syndrome, hypokalaemic alkalosis with hypercalciuria, is caused by mutations in the Na-K-2Cl cotransporter NKCC2. Nat Genet 13:183-188

3. Simon DB, Karet FE, Rodriguez-Soriano J, Hamdan JH, DiPietro A, Trachtman H, Sanjad SA, Lifton RP 1996 Genetic heterogeneity of Bartter's syndrome revealed by mutations in the K+ channel, ROMK. Nat Genet 14:152-156

4. Simon DB, Bindra RS, Mansfield TA, Nelson-Williams C, Mendonca E, Stone R, Schurman S, Nayir A, Alpay H, Bakkaloglu A, Rodriguez-Soriano J, Morales JM, Sanjad SA, Taylor CM, Pilz D, Brem A, Trachtman H, Griswold W, Richard GA, John E, Lifton RP 1997 Mutations in the chloride channel gene, CLCNKB, cause Bartter's syndrome type III. Nat Genet 17:171-178

5. Birkenhager R, Otto E, Schurmann MJ, Vollmer M, Ruf EM, Maier-Lutz I, Beekmann F, Fekete A, Omran H, Feldmann D, Milford DV, Jeck N, Konrad M, Landau D, Knoers NV, Antignac C, Sudbrak R, Kispert A, Hildebrandt F 2001 Mutation of BSND causes Bartter syndrome with sensorineural deafness and kidney failure. Nat Genet 29:310-314

6. Vargas-Poussou R, Huang C, Hulin P, Houillier P, Jeunemaitre X, Paillard M, Planelles G, Dechaux M, Miller RT, Antignac C 2002 Functional characterization of 
a calcium-sensing receptor mutation in severe autosomal dominant hypocalcemia with a Bartter-like syndrome. J Am Soc Nephrol 13:2259-2266

7. Watanabe S, Fukumoto S, Chang H, Takeuchi Y, Hasegawa Y, Okazaki R, Chikatsu N, Fujita T 2002 Association between activating mutations of calcium-sensing receptor and Bartter's syndrome. Lancet 360:692-694

8. Konrad M, Vollmer M, Lemmink HH, van den Heuvel LP, Jeck N, Vargas-Poussou R, Lakings A, Ruf R, Deschenes G, Antignac C, Guay-Woodford L, Knoers NV, Seyberth HW, Feldmann D, Hildebrandt F 2000 Mutations in the chloride channel gene CLCNKB as a cause of classic Bartter syndrome. J Am Soc Nephrol 11:14491459

9. Colussi G, De Ferrari ME, Tedeschi S, Prandoni S, Syren ML, Civati G 2002 Bartter syndrome type 3: an unusual cause of nephrolithiasis. Nephrol Dial Transplant 17:521-523

10. Tajima T, Nawate M, Takahashi Y, Mizoguchi Y, Sugihara S, Yoshimoto M, Murakami M, Adachi M, Tachibana K, Mochizuki H, Fujieda K 2006 Molecular analysis of the CLCNKB gene in Japanese patients with classic Bartter syndrome. Endocr J 53:647-652

11. Fukuyama S, Okudaira S, Yamazato S, Yamazato M, Ohta T 2003 Analysis of renal tubular electrolyte transporter genes in seven patients with hypokalemic metabolic alkalosis. Kidney Int 64:808-816
12. Jeck N, Konrad M, Peters M, Weber S, Bonzel KE, Seyberth HW 2000 Mutations in the chloride channel gene, CLCNKB, leading to a mixed Bartter-Gitelman phenotype. Pediatr Res 48:754-758

13. Peters M, Jeck N, Reinalter S, Leonhardt A, Tonshoff B, Klaus GG, Konrad M, Seyberth HW 2002 Clinical presentation of genetically defined patients with hypokalemic salt-losing tubulopathies. Am J Med 112:183-190

14. Fukuyama S, Hiramatsu M, Akagi M, Higa M, Ohta T 2004 Novel mutations of the chloride channel $\mathrm{Kb}$ gene in two Japanese patients clinically diagnosed as Bartter syndrome with hypocalciuria. J Clin Endocrinol Metab 89:5847-5850

15. Watanabe T, Tajima T 2005 Renal cysts and nephrocalcinosis in a patient with Bartter syndrome type III. Pediatr Nephrol 20:676-678

16. White SJ, Sterrenburg E, van Ommen GJ, den Dunnen JT, Breuning MH 2003 An alternative to FISH: detecting deletion and duplication carriers within 24 hours. J Med Genet 40:e113

17. Thomas AC, Cullup T, Norgett EE, Hill T, Barton S, Dale BA, Sprecher E, Sheridan E, Taylor AE, Wilroy RS, Delozier C, Burrows N, Goodyear H, Fleckman P, Stephens KG, Mehta L, Watson RM, Graham R, Wolf R, Slavotinek A, Martin M, Bourn D, Mein CA, O'Toole EA, Kelsell DP 2006 ABCA12 is the major harlequin ichthyosis gene. J Invest Dermatol 126:2408-2413

18. Stankiewicz P, Lupski JR 2002 Genome architecture, rearrangements and genomic disorders. Trends Genet 18:74-82

\section{Erratum}

Table 1 of the article, "American Pediatric Society Presidential Address: Science on the edge with life in the balance" by David K. Stevenson (Pediatr Res 60:630-635) contained an error. The "Ambulatory Pediatric Association of Program Directors" was incorrectly listed. The correct name of the society is "Ambulatory Pediatric Association". The author regrets the error. 